\title{
“Put Your Own House In Order First": Local Perceptions of EU Influence on Romani Integration Policies in the Czech Republic
}

\author{
Laura Cashman
}

\begin{abstract}
This paper examines the influence of the European Union (EU) on the development and implementation of Romani integration policy in the Czech Republic from the perspective of those responsible for policy delivery. Based on analysis of key policy documents and research conducted in the Czech Republic, this paper first examines how Romani integration became a more important issue during membership negotiations and then discusses how the criticism of the European Commission's Regular Reports was received by those responsible for implementing pro-Romani policies. Finally, the paper assesses how the status of full EU membership has impacted on integration policy. The paper concludes that while funding for Romani integration projects has benefitted some groups, the overall impression of the EU is of a remote institution, quick to criticise and unwilling to practise what it preaches.
\end{abstract}

ROMA HAVE BEEN LIVING IN EUROPE FOR AT LEAST SIX HUNDRED YEARS AND WHILE there is significant diversity between Romani communities ${ }^{1}$ across Europe, they share a common history of exclusion, discrimination and persecution (Barany 2002; Fraser 1995). With the accession of Bulgaria and Romania to the EU in 2007, the population of Romani citizens in the European Union (EU) could be as high as ten million, although the best estimates range between three and six million (DG Employment and Social Affairs 2004: 6). As a result, the question of how to integrate Romani communities has become a higher priority within EU institutions. In 1998 the Reflection Group on the Long-Term Implications of EU Enlargement highlighted the particular needs of Romani citizens and recommended "direct EU involvement where a minority issue transcends the borders of member-states" (Amato and Batt 1998: 1). The need for EU involvement

\footnotetext{
1 This paper refers to Romani communities and Roma rather than the Romani community in acknowledgement of the heterogeneity of Romani communities in the Czech Republic and in Europe more generally. Roma vary widely from those who still adhere to customs and traditions to those who have little knowledge of their Romani heritage. Roma also differ in terms of socio-economic status; a growing middle class of well-educated Roma exists but EU and Czech policy is currently concerned with Roma who live in the worst housing conditions, who do not have any educational qualifications and who struggle to find employment. This is not to imply, however, that this socio-economic group represents all members of Romani communities or that the Romani identity is inevitably linked to deprivation and anti-social behaviour.
}

I would like to thank everyone who provided feedback on the paper: Eamonn Butler and Aidan McGarry, the anonymous reviewers and those who attended the presentations of earlier versions of this paper at the BASEES and PSA conferences in 2007.

Cashman, L. (2008). "'Put Your Own House In Order First”: Local Perceptions of EU Influence on Romani Integration Policies in the Czech Republic', Journal of Contemporary European Research, Vol. 4, No. 3, pp. 193-208. Available: http://www.jcer.net/ojs.index.php/jcer/article/view/112/105 
in protecting Romani rights has not lessened in the intervening years. Indeed, in many ways the plight of Roma has actually worsened since the 1990s (Ringold et al. 2005: 9 10).

This paper explores how the EU has influenced policies to support the integration of Romani communities, using the Czech Republic as a case study of an EU applicant state. Very little reliable statistical data is available about Roma but it is generally accepted that there are approximately 250,000 - 300,000 Roma living in the Czech Republic, i.e. almost three per cent of the population. ${ }^{2}$ They live in urban and rural settlements all over the country, but the largest concentrations of Romani inhabitants are to be found in the industrial cities of northern Bohemia and northern Moravia. Any Roma still living a nomadic lifestyle following the assimilation policies of Empress Maria Theresa in the $18^{\text {th }}$ century and the extermination policy of the Nazi regime were finally forcibly settled during the communist period (Guy 1975: 214). The communist assimilation policies were successful in the sense that illiteracy rates among Roma fell significantly (Ulč 1988: 318) and by 198175 per cent of working age Romani men and women were employed, mainly as unskilled labourers in heavy industry (Kostelancik 1989: 315). With the fall of communism in 1989 and the subsequent economic reforms, many Roma suffered as they lost their low-skilled jobs and social welfare benefits were reduced or withdrawn (Barany 2002: 172 - 176). The Ministry of Labour and Social Affairs (MLSA) does not keep precise statistics on how many Roma are unemployed, considering this to be a breach of the regulations on collecting data about citizens according to their ethnicity. However, in 2003 the MLSA estimated that Roma made up almost a third of all those registered as unemployed, despite the fact that Roma account for only about 3 per cent of the population (MLSA 2003a: 1.2).

This paper first examines how Romani integration became a more important issue during membership negotiations. This is apparent from the increased interest paid to the issue in the Regular Reports published by the European Commission on the readiness of the Czech Republic for membership, the sudden increase in momentum with regard to developing a Czech national integration strategy, and statements made by politicians and in official reports linking EU membership to finding a solution to the problem of Romani social exclusion. The main part of the paper discusses how officials and practitioners at the local level perceived the influence of EU pressure on the situation locally. Finally, the paper reflects on the implications of achieving EU membership for the Romani integration project. Much published research has focused on the influence of the EU accession negotiations on the development of Romani integration policy (Guglielmo and Waters 2005; Guy 2001; Kovats 2001; Ram 2003; Vermeersch 2004). Recently, Spirova and Budd (2008) published a study which used survey data to measure how the socio-economic status of Roma changed during the accession process. Drawing on qualitative empirical data, this paper adds a further dimension to the literature by analysing the perspectives of individuals responsible for policy delivery at the local level.

\section{Romani policy and the EU accession negotiations}

A body of literature is gradually emerging which examines the impact of the 1993 Copenhagen Criteria for EU membership (specifically the demand for "respect for, and protection of minorities") on the development of minority and Romani integration policies in Central and Eastern Europe (CEE) (Hughes and Sasse 2003; Johns 2003; Kelley

\footnotetext{
2 According to the 1991 census when "Romani" was included as a nationality category for the first time, 32,903 people identified themselves as such (Guy 2001: 315). Ten years later, the 2001 census recorded a Romani population of only 11,716 (CSO 2001). In spite of this, it is generally accepted that the true figure lies between 250,000 and 300,000 (Liégeois and Gheorghe 1995). Reasons for the reluctance of Roma to register themselves include fears about how the information will be used and misunderstandings about the difference between the categories of nationality and citizenship.
} 
2004; Ram 2003; Spirova and Budd 2008). However, as these authors also acknowledge, the EU was not the only international organisation to put pressure on CEE states to improve their treatment of national and ethnic minorities. The OSCE and Council of Europe were particularly influential in the 1990s, highlighting cases of minority rights abuses in CEE such as, for example, the problems Czech Roma had in obtaining citizenship in the new Czech Republic (Council of Europe 1996; OSCE/CSCE 1993). Further, Vermeersch (2004: 8) argues that the plight of Roma in the candidate countries was not a high priority for the Commission when the Copenhagen Criteria were developed in 1993, because unlike national minorities with territorial claims, "they were not perceived as a potential threat to European stability". This changed over the course of the 1990s as non-governmental organisations (NGOs) highlighted the problems facing Roma and the numbers of asylum seekers arriving in EU member states grew (Ram 2003; Klímová 2004).

The key development in the mid-1990s, which caught the attention of the international media and pushed the interests of Roma of CEE much higher up the political agenda, was the dramatic rise in the numbers of Roma seeking asylum in Western states. As grounds for asylum, they cited fear of physical attacks by skinheads and the general failure of the authorities to protect them from discrimination. It is difficult to establish exactly how many Roma travelled abroad to claim asylum as most states record claims based on the nationality of the individual rather than their ethnicity but Guy (2004: 190) estimates that about 1,500 Roma applied for asylum in the UK in 1997, accounting for about 4 per cent of all asylum seekers that year. Klímová (2004: 16) cites the reports of EU governments estimating that from 1997 to 2000 between 85 and 99 per cent of asylum claims made by Czech citizens were made by Roma. The tactic of applying for asylum has been analysed in depth by many scholars (see Castle-Kaňerová 2003; Guy 2004; Klímová 2004; Matras 2000) and the reasons why Roma chose the asylum process as a means to migrate to the West will not be discussed here. Instead, the focus is on the impact this "wave" of asylum seekers from the Czech Republic had on EU membership negotiations and how it acted as a motivational factor in the acceleration of the development of pro-Romani policies. For example, Uherek (2004: 87) reports that in 1997 about 1,500 Roma Czech Roma sought asylum in Canada, prompting the Canadian authorities to re-introduce visas for all Czech citizens. Matras (2000: 47) argues that the asylum seekers forced the international community to pay more attention to the plight of Central and East European Roma which led to more pressure being exerted on governments to take action to stem the flow of would-be refugees. An examination of the resolutions passed by Czech governments from the early 1990s until EU membership was achieved in 2004 provides evidence of a sharp increase in activity in 1997. Between 1991 and 1996, successive Czech governments passed 12 resolutions concerning Romani communities. In the following six years, between 1997 and 2003, 86 resolutions were passed (Council for Romani Community Affairs 2005a). This sudden increase in momentum in developing pro-Romani policy is certainly linked to the pressure coming from states that were dealing with the asylum claims of Czech Roma, as well as the opening of EU accession negotiations.

Based on the evidence of the Regular Reports published annually by the Commission between 1997 and 2002, it is clear that Romani integration became a higher priority over time. The first commentary published by the Commission, in 1997 indicated that the Czech Republic fulfilled the Copenhagen Criteria regarding treatment of minorities. However, the Opinion also commented on particular problems facing Roma, noting the inadequacy of police protection from attacks by skinheads, discrimination in the spheres of housing and employment and the unfair terms of the Citizenship Law (European Commission 1997: 16). The 1998 Regular Report criticised the widespread discrimination against Roma in society, particularly regarding access to social services. Significantly, the rise in the numbers of asylum seekers was also noted (European Commission 1998: 10 - 11). The Reports all comment on the high-profile issues of the day, including the controversy over the wall in Ústí nad Labem in 1999 (European Commission 1999: 16) and the European Roma Rights Centre (ERRC) court case citing 
discrimination in the education system in 2000 (European Commission 2000: 26). Problems with social exclusion and discrimination were highlighted in the 2001 and 2002 Reports and the 2003 Report again called for comprehensive anti-discrimination legislation (European Commission 2003: 35). The general conclusion of each Report was that although the Copenhagen Criteria had been fulfilled, the Commission wished for more to be done to improve the integration of Romani communities.

In January 1997, Pavel Bratinka, President of the Council for National Minorities, commissioned the Report on the situation of the Romani community in the Czech Republic (hereafter the Bratinka Report). It was approved on 29 October 1997, days before the collapse of Klaus' ODS government (Government Resolution 1997b) and its adoption was welcomed in the 1998 Regular Report (European Commission 1998: 10). Based on the experiences of state and local government officials and NGO representatives working with Roma, the Bratinka Report described the problems facing Romani communities, particularly the socio-economic problems and the discrimination against Roma in Czech society (Government of the Czech Republic 1997: 3.I.1). Importantly, it acknowledged that the criticisms of international institutions regarding the failure of the Czech government to address the problems of Romani communities were justified (Government of the Czech Republic 1997: 3.ii).

The Inter-ministerial Commission for Romani Community Affairs was established in September 1997 to improve the representation of Roma at the state level and to make policy proposals to improve the integration of Romani communities (Government Resolution 1997a). In 2001, the Commission was transformed into a permanent advisory body - the Council for Romani Community Affairs (Government Resolution 2001). 14 members represent the state administration - these are mostly deputy ministers - and 14 members are appointed on a regional basis to ensure fair representation of Roma from across the country (Council for Romani Community Affairs 2003: 2.2.3). The main achievement of the Council for Romani Community Affairs has been the development of the Concept of Government Policy Towards Members of the Romani Community Designed to Facilitate their Social Integration (hereafter the 2000 Concept). Approved on 14 June 2000, the 2000 Concept sets as its goal, the integration of Romani communities within twenty years (Government Resolution 2000).

It can certainly be argued that pressure from the European Commission had a positive effect on the development of Romani integration policy at the state level. Vermeersch (2004: 13) argues that the controversy of the Romani asylum seekers in 1997 was exploited by civil servants to raise the profile of the Bratinka Report, which was published while the Civic Democrats (ODS) were still in power. From 1998 the new Social Democrat (ČSSD) minority government used the proposals of the Bratinka Report as a starting point to find new ways to approach Romani integration. The continuity of policy pursued by the two main political parties, who generally take very different stances on the main electoral issues, is further evidence that EU pressure was taken very seriously.

Officials often stated publicly that the question of Romani integration was an important factor in the accession negotiations. In 1998 Rals Dreyer, acting head of the EU mission in the Czech Republic announced: "Romani rights have become one of the most important issues of EU accession negotiations" (cited in Barany 2002: 27). On a state visit to Latvia in November 1999, Prime Minister Zeman noted that the way his government handled Romani policy could influence the Czech Republic's accession to the EU (Lidové noviny 1999). President Václav Havel also claimed in 1999 that the ability of Czechs and Roma to integrate had a direct influence on the reputation of the country in Europe. If "co-existence" could not be achieved then the state could "forget about integrating into Europe and into the European Community" (cited in O'Nions 1999: 7). The Bratinka Report and the 2000 Concept refer to the criticism from international institutions (Government of the Czech Republic 1997:3.ii; 2000: 12.4) and 
the 2005 Updated version of the Concept specifically links membership of the EU with the development of its Romani policy:

In connection with the entry of the Czech Republic into EU, the government has undertaken to make use of all new and available means helping social inclusion of members of Roma communities. (Council for Romani Community Affairs 2005b: 1.12)

The case of how much influence the EU exerted on the development of Romani integration policy should not be overstated, however. Vermeersch (2004: 14) cites the example of the Act on the Rights of Members of National Minorities, passed in 2001. The EU had not requested such a law but the government decided to introduce it. On the other hand, the Regular Reports repeatedly highlight the need for comprehensive anti-discrimination legislation (European Commission 2001; 2003) but this legislation has still not been ratified, as will be discussed below. It is also difficult to distinguish differences between the impact of EU pressure as opposed to the activities of NGOs. One significant example is the case brought against the Czech Republic to the European Court of Human Rights (ECHR) in 2000 by Romani families with the support of the international advocacy NGO the European Roma Rights Centre (ERRC). They claimed that educational psychologists were placing disproportionate numbers of Romani children in remedial special schools. Even before the ECHR Grand Chamber found in favour of the families in 2007, the guidelines about assessing children with special educational needs were tightened up and in 2004 remedial special schools were abolished as part of wider education reforms (Education Act 2004).

\section{Romani policy at the local level}

Having established that EU pressure had an impact on the development of Romani policy at the state level, this article will now turn to the question of how EU influence was perceived locally. Guy $(1975 ; 2001)$ argues that the likelihood of any pro-Romani reforms succeeding in the Czech Republic is determined by the degree to which the proposals are supported by local authorities. This resonates with Lipsky's (1980) theory of the influence of "street-level bureaucrats" on how policies are delivered. Given the decentralisation of political power to the municipal level in the Czech Republic, responsibility for the implementation of Romani policy rests to a large extent with local authorities. The state authorities develop the policy framework but the measures have to be implemented by officials in the municipalities. Furthermore, where municipal authorities have specific competencies according to the constitution, they are not bound by government resolutions and cannot be instructed to implement particular programmes or policies. The management of primary schools is an example of such a competence. This issue has been acknowledged in the Updates to the 2000 Concept and proposed solutions to the problem include offering municipalities more financial support in return for implementing integration strategies and improving cooperation and communication with organisations such as the Union of Cities and Municipalities and the Association of Regions (Council for Romani Community Affairs 2005b: 12).

The discussion in this section is based on the findings of research examining the development and implementation of a range of policies to support the social inclusion of Romani communities at the local level in the Czech Republic. ${ }^{3}$ Research consisted of an extensive review of the key legislation and policy documents produced by the Council for Romani Community Affairs and the Ministries of Education and of Labour and Social Affairs followed by fieldwork conducted in České Budějovice and Ostrava, over a period of four months between October 2004 and May 2005. This was followed up by visits to both cities in October/November 2007. In total, approximately 100 people - local Romani Advisors, municipal and regional officials in the departments of

\footnotetext{
${ }^{3}$ Research conducted in the period 2004 - 2005 was funded by the ESRC (PTA-030-2002-01172) and a Europe-Asia Studies scholarship.
} 
education, social welfare and employment, representatives of NGOs supporting Romani communities, school principals, teaching assistants, social workers and field social assistants - were interviewed. ${ }^{4}$

The decision to select Ostrava and České Budějovice as fieldwork sites was based on the premise that the significant differences between the two cities in terms of the size of the Romani populations and the experiences of economic transition in the 1990s would allow for an interesting comparative analysis. Ostrava, capital of the MoraviaSilesia Region, is the third largest city in the Czech Republic with a population of 320,000 , of which approximately 20,000-30,000 are estimated to be Roma. České Budějovice, capital of the South Bohemia Region is an average sized Czech city with a population of approximately 90,000 and a proportionally smaller Romani population of $2,500.5$

Ostrava has traditionally been a key industrial centre with significant coal and steel enterprises. In the communist period many migrants were attracted to the city, including many Roma from rural Slovakia. However, the economic transition in the 1990s had an extremely negative impact on the city and as subsidies for heavy industry were withdrawn, unemployment levels increased alarmingly, peaking at 18.4 per cent in 2004 (Czech Statistics Office 2008a). In 2005 when the first stage of research was conducted, the unemployment rate in Ostrava was one of the highest in the country at 15.3 per cent (MLSA 2006). In 2007 this had fallen to 9.4 per cent but it is still among the highest rates in the country (Czech Statistics Office 2008b). České Budějovice on the other hand, is one of the success stories of the transition period, largely thanks to the diverse nature of the industries in the region. In 2005 the unemployment rate was 3.9 per cent (MLSA 2006). The rate was 3.8 per cent in 2007 (Czech Statistics Office 2008b).

Ostrava is an interesting case study because many of the policies now being promoted as part of the Czech integration strategy were first piloted by NGOs in the city. The first preparatory classes and teaching assistants were introduced in Ostrava schools and the municipal authorities employed the first field social assistants in the country. However, Ostrava gained notoriety when a group of Romani schoolchildren and their parents took the city's education services to the ECHR in Strasbourg in 2000. With the assistance of the ERRC, an international Romani Rights NGO, they argued that the city's schools and educational psychologists deliberately discriminated against Romani children. They claimed that they were denied education in mainstream schools because biased officials and poor testing procedures caused a disproportionate number of Romani pupils to be misdiagnosed with learning difficulties and placed in remedial special schools. The families initially lost the case but appealed the decision to the Grand Chamber of the ECHR, which found in their favour on 14 November 2007 (ERRC 2008).

Given the size of the city and the smaller proportion of Romani inhabitants, České Budějovice does not have a high profile in terms of Romani issues. However, this does not mean that Romani social exclusion is less of a problem in the city. High numbers of Romani pupils attended the local remedial special school and the lack of qualifications and skills among adults mean many adult Roma are unemployed despite the generally low level of unemployment in the city. Spatial exclusion is a growing problem as nonRoma increasingly move away from areas with a high concentration of Romani residents. Therefore, although the small size of the city's Romani population should mean that integration would be easier, this has not proved to be the case thus far.

\footnotetext{
${ }^{4}$ To protect their anonymity, respondents will be referred to only by the position they held at the time of interview and the city where they worked.

${ }^{5}$ Census data on Roma is notoriously unreliable and these estimates were provided by officials responsible for Romani affairs in both cities.
} 
There were marked differences in how national Romani policy has been implemented in both cities and these will be described briefly here. Education programmes to support Romani pupils have been more effective in schools in Ostrava than in České Budějovice. Preparatory classes were cancelled in České Budějovice because not enough parents were enrolling their children. In Ostrava, however, poor attendance rates did not deter the principals who believed that the programme was useful and worth persevering with (Cashman 2008: 167 - 168). The employment of Romani Teaching Assistants (TAs) in primary schools had been very successful in Ostrava and the principals of the schools where they worked were very happy with the contribution they made to lessons. However, in the school year 2004/05 only one school in České Budějovice employed a Romani TA. Other principals claimed that they would be willing to employ Roma but no suitably qualified candidates were available. In 2007 there were no Romani TAs working in České Budějovice. ${ }^{6}$

The policies to create employment opportunities for Roma in the private sector were more successful in České Budějovice, where as a result of the generally low unemployment rate, Roma had less competition for placement opportunities. In Ostrava, in 2005, where unemployment was high among non-Roma as well as among Roma, the training schemes were less successful and it was more difficult to find employers willing to take on unqualified Roma as trainees. However, the significant fall in the general unemployment rate in 2007 meant that opportunities were gradually opening up for Romani job seekers (Employment Office Representative 2 2005; 2007). Romani Field Social Assistants (FSAs) were employed in Ostrava to work directly in communities with large Romani populations. They worked with long-term unemployed Roma and encouraged them to find employment. There were no FSAs working in České Budějovice in 2004 but in 2007 the municipal authorities employed two Field Social Assistants.

\section{Perceptions of EU influence on integration policy}

When respondents were asked about the influence the EU had on Romani integration policy, the main themes which emerged were their annoyance that they were being criticised by officials from states where the living conditions of Roma were little better than in the Czech Republic and their appreciation for the funding and exchange opportunities which they had used to learn more about how minority issues were dealt with in other parts of the EU. Opinions differed on the question of whether EU membership had really had much influence on Romani policy at the local level. These themes will be explored in more detail in this section.

The most common reaction to the question of how EU influence was perceived was irritation that the way Roma were treated in the Czech Republic was being criticised by commentators and EU officials who did not fully understand the local context. Many respondents, especially those in positions of authority believed that these critics were not in full possession of the facts because they only heard the version of the story presented by NGOs who had their own agenda to pursue. They also thought that some issues had been blown out of proportion by the media. For example school principals and educational psychologists were angered by the claims of discrimination in the education system. (These claims were later upheld by the Grand Chamber of the ECHR.) NGO representatives on the other hand tended to be more measured in their responses. While they welcomed international interest in their problems, they acknowledged that when criticism was perceived as 'foreign' interference it could actually make their work with local authorities more difficult. Furthermore, many respondents were annoyed that the way Roma in the Czech Republic lived was under

\footnotetext{
${ }^{6}$ Interviews conducted by the author with principals of primary schools and local education officials in České Budějovice in October and November 2004 and November 2007 and in Ostrava, March to May 2005 and October 2007.
} 
attack, when the situation was not much better in many of the 'old' EU member states. They cited the problems with finding suitable halting sites ${ }^{7}$ for Travellers in West European states and they argued that even if many Romani children were educated in special schools at least they were literate, which was often not the case for Romani and Gypsy-Traveller children in 'old' EU member states. They also complained that it was unfair for EU officials to always criticise their policies without offering alternative policy solutions. The views of an education official in České Budějovice and an educational psychologist working in the Moravia-Silesia Region were representative of the majority of respondents:

It is true that when Minister [Eduard] Zeman was Minister for Education [1998 - 2002], EU organs examined the Czech special education system in quite a significant way and we often received warnings that we discriminated against children. I would like to point out that some countries in Western and South-Western Europe create reservations for Romani citizens where they camp. The children can't read or write, which doesn't happen in the Czech Republic. It would be worth remembering the Czech proverb "put your own house in order first". (South Bohemia Regional Education Official 2004)

I wish people would criticise and then show us how to do things better but only to criticise and offer no suggestions isn't right. We have been doing our best for 40 years. (Educational Psychologist 2005)

These criticisms of the EU resonate with wider literature noting the double standards which existed between what was expected of states applying to join the EU compared to existing members (Johns 2003; Pridham 2008). Ram (2003) argued that the antiRomani prejudices which existed in member states weakened the authority of the Commission when it demanded more rights for minorities in applicant states. She uses the checkpoints established by British officials at Prague's Ruzyně airport in 2001 to prevent Romani asylum seekers from boarding flights to Britain to illustrate her point (Ram 2003: 48). Riedel (2001: 1266) noted a growing frustration within applicant states as they saw the EU "moving the goalposts" in terms of what was expected. She argues this led to cynicism and the belief that the applicant states would never enter the EU because they could never fulfil all the demands placed upon them. This cynicism was reflected in many of the comments made by respondents who resented the criticism made by the European Commission and other international organisations and NGOs. It should be noted that when the Regular Reports were compiled, they were based on a wide range of reports and research conducted by experts who were very familiar with the circumstances in each state. However, this sensitive reporting was lost on local officials who did not read the reports but instead got the gist of their content from the national media.

However, the EU was not viewed in a completely negative light; officials, principals and NGO representatives all welcomed the new funding opportunities that membership brought. Between 1993 and 2001 the EU donated $€ 8,127,600$ through Phare programmes for Roma in the Czech Republic to fund education and training, antidiscrimination programmes, Romani publications and other cultural projects (DG Enlargement Information Unit 2003: 21). NGOs and schools in both cities had used EU funding for programmes to support Romani integration. Two principals (one from Ostrava and one from České Budějovice) had participated in exchange programmes to the Netherlands and they talked about policies which they thought might be adapted to benefit pupils in their schools. However, they were unsure that any real solutions had been found which they could apply with ease (Principal 3 2004; Principal 7 2005). One official in Ostrava's municipal education department rejected the idea that a 'onesize-fits-all' EU policy would be of any use:

I have the feeling that the Romani question will be resolved in each state according to their traditions and I think maybe in Hungary they will deal with it one way and in Poland they will

\footnotetext{
7 These are permanent campsites provided by municipal authorities for Travellers who still live a nomadic lifestyle.
} 
do something different and here also. I don't think the EU could give us some universal guidelines to resolve this problem. They want us to solve it but how? (Municipal Education Official 2005)

More recent interviews (2007) focused on the use of EU structural funds to aid Romani integration. These had been used to good effect in Ostrava, where Roma were finding more opportunities for employment as investment was made in infrastructure development. However, the process of applying for funding for specific pro-Romani projects was seen as arduous and complicated by too much red tape. This problem had already been identified when Phare funds were being distributed and has not yet been fully resolved (DG Enlargement 2004: 7). A worrying development reported by officials was that schools and NGOs felt they were competing against each other for funding and were reluctant to share know-how or resources with one another. This resulted in many applications not being as good as they could be but officials were unsure how to overcome this problem (Employment Office Representative 2 2007; NGO representative 12 2007; Romani Advisor 2007).

While the EU cannot directly influence the education or social welfare policies which are the main elements of the Romani integration strategy, it could be expected that the pressure to improve Romani social inclusion would filter down to local authorities via the state institutions. Indeed, analysis of the comments of respondents in both cities regarding the influence of the EU revealed an interesting pattern - perceptions of EU influence reflected attitudes to Romani integration policy as a whole. In České Budĕjovice, where pro-Romani policies were not high on the agenda and where few reforms had been successfully implemented, the officials felt as if criticism from Brussels had little impact. A senior member of the municipal council stated:

It didn't have any influence because we were dealing with these problems without Brussels. It's true that thanks to Brussels there are more possibilities now how to deal with it, but we've been resolving these problems for many years. It had no influence on whether or not we would join the EU. (Municipal Councillor 2004)

On the other hand, officials in Ostrava, where the local administration had been more proactive when it came to implementing policies and developing new initiatives to support Roma, viewed the influence of the EU differently. A senior official in the regional education department based in that city thought that the reform process had been accelerated because of EU pressure:

I think for us in education it was accelerated or the emphasis on that was increased, that fewer children should end up in special schools and more than that, that they should be integrated, so the process was accelerated, the problems were emphasised. I think it would have happened without Brussels, but more slowly, I think this speeded it up. (Regional Education Official 2005)

The statements of these officials indicate that their interpretation of EU pressure matched their general level of enthusiasm for the integration project. However, they also reflected the power struggles taking place between the different tiers of government and administration. The officials saw that pressure was exerted on the central government to implement changes but at the local level they felt further removed from Brussels. In České Budějovice, Romani integration was not a priority and the municipal authorities were resisting pressure from the central government to devote more attention to the local Roma community (Cashman 2008: 169). Therefore, they also ignored criticism from Brussels. In Ostrava, where the problems of the Romani community were too great to ignore, officials were already working with NGOS to find ways to improve the integration of local Romani communities. Therefore, these officials welcomed EU interest and the pressure placed on the central government to invest more in pro-Romani programmes, as they hoped it would assist them in implementing their policies. 


\title{
How influential has membership been?
}

The Czech Republic joined the EU in May 2004 and four years on we can begin to reflect on how membership has impacted on integration policy. Guglielmo (2004: 42) has noted that once the membership of CEE candidates was confirmed in May 2004, monitoring of their minority policies would cease, given that "membership, paradoxically, requires less minority protection than candidacy". One Romani official interviewed in October 2004 worried that as membership had been achieved all the fuss would die down and the initiatives developed to ensure accession would be gradually forgotten:

\begin{abstract}
Now the latest information we have - now we are members of the EU - we hear that they are planning to dissolve the Council [of Romani Affairs], to get rid of the function of Romani advisors, that advisors should no longer exist. All the activists are afraid that they will lose their jobs. Organisations which cover us, who helped, they ran seminars, meetings, training, all of that will go down the plughole if they cancel it. (South Bohemia Regional Coordinator for Romani Affairs 2004)
\end{abstract}

Thus far such fears have not been realised. The ČSSD-led coalition government from 2002 to 2006 did not make any significant changes to Roma policy following EU accession. The ODS minority government of $2006^{8}$ did reduce the staff of the secretariat of the Council for Romani Community Affairs from five to four as part of a drive to reduce government bureaucracy (Litomiský 2006). However, as noted above there is cross-party agreement that Romani policies must be supported and the ODS, Christian Democrat and Green Party coalition government has continued to fund new Romani integration initiatives. The most important of these is the development of a new government agency for social inclusion in Romani localities (Government of the Czech Republic 2008).

Despite some positive developments, hopes that EU membership would secure further rights for Roma through the introduction of anti-discrimination legislation have not been realised (Guglielmo 2004; Mirga 2005). The Race Equality Directive (Directive 2000/43/EC), which implements the principle of equal treatment between persons in all spheres of life irrespective of racial or ethnic origin, was adopted on 29 June 2000. Prospective EU member states, including the Czech Republic, were required to adapt their legislation to comply with the requirements of the Directive, which was due to come into force immediately after membership was finalised in May 2004. However, in June 2008 the Czech Republic still had not fully implemented the Directive. Czech legislation dealing with discrimination is very complex because there is no single act covering all aspects of defining, prohibiting and prosecuting discriminatory acts in all spheres of life. This is a problem to which successive Czech governments have sought a solution. In February 2002, the Report on Possible Measures to Combat Discrimination which addressed the question of how best to implement both the Race Equality and General Framework Directives ${ }^{9}$ was approved by parliament. This report proposed introducing a general law forbidding all forms of discrimination, which would apply to all matters under civil law (Government of the Czech Republic 2002: 30). In December 2005, almost three years after the report was published, the Chamber of Deputies (lower house of parliament) passed an anti-discrimination bill complying with all the conditions laid out in the EU directives and covering race along with an exhaustive list of other possible grounds for discrimination including age, gender, disability, religion,

\footnotetext{
8 The complicated stalemate which arose after the June 2006 national elections resulted in an ODS minority government being in power for a brief period from 4 September to 3 October 2006. The ODS minority government failed to win a vote of confidence in October 2006 and on 19 January 2007 a fragile coalition government of ODS, the Christian Democrats and the Green Party was finally approved by Parliament.

${ }^{9}$ The General Framework Directive (Directive 2000/78/EC), establishing a general framework for equal treatment in employment and occupation addressed discrimination based on disability, age, religious belief and sexual preference (but not race or ethnicity), was adopted in November 2000 and is the other main element of EU anti-discrimination legislation.
} 
and sexual orientation (Pravec 2005). However, the bill was rejected by the Senate and returned to the Chamber of Deputies in January 2006 because senators considered the wording of the bill to be too vague (Hospodárské noviny 2006). Facing increased pressure from the European Commission, a renegotiated bill was passed by the Chamber of Deputies on 19 March 2008 and by the Senate on 30 April 2008 but was then vetoed by Czech President Václav Klaus "as superfluous and counterproductive" on 16 May 2008 (iDnes.cz 2008). The bill will be returned to the Chamber of Deputies, where a simple majority of members can vote to overturn the veto.

Any assessment of how EU membership has affected Romani integration policy in the Czech Republic must conclude that the results thus far are mixed. There is cross party agreement that socially excluded Roma require state support and this is available to regions and municipalities interested in accessing it. However, on issues such as antidiscrimination legislation differences emerge, with some politicians on the right, and indeed the president, viewing the creation of a new law as unnecessary. The delays with this bill reflect the failure of successive weak governments with small majorities to pass legislation. The Commission has not yet invoked the formal infringement proceedings which could be applied should the legislation be further delayed although the government is aware of this threat and for this reason it is expected that the legislation will be passed at its next reading in the Chamber of Deputies.

\section{Conclusion}

This article has examined the influence of the EU on the development of policies and programmes to support the integration of Romani communities. It is not by chance that the development of pro-Romani policies gained momentum during the accession negotiations and this has been acknowledged by politicians and in the key policy documents relating to Romani integration. However, the implementation of the integration strategy is the responsibility of local authorities at the regional and municipal levels and here it would appear that commentary and criticism from the EU had less impact. While some respondents had benefited from EU funding for particular projects and exchange programmes, the overall impression of the EU is of a remote institution which is quick to criticise and unwilling to practise what it preaches. The remoteness of the EU from ordinary citizens is well documented. Therefore, it should not come as a surprise that the situation is no different when it comes to ensuring the implementation of policies to support Romani communities. Until the EU itself takes steps to introduce EU-wide support for Romani rights and other minority rights, the integration of Romani communities in the Czech Republic will remain dependant on national policy, and in turn, on how that policy is interpreted at the local level. However, it must also be acknowledged that unless new strategies developed at the EU level are recognised as practical and useful to local authorities, they are unlikely to be effective. At the very least the Commission should continue to apply pressure to the Czech government to ensure that comprehensive anti-discrimination legislation is finally passed.

\section{References}

Act on the Rights of Members of National Minorities (2001). Code of Laws No.273/2001 Coll., Part 104, Page 6461. Available at: http://www.mvcr.cz/sbirka/2001/sb10401.pdf, last accessed 22 October 2006.

Amato, G. and Batt, J. (1998). Minority rights and EU enlargement to the east. Report of the first meeting of the Reflection Group on the Long-term Implications of EU 
Enlargement: The nature of the new border. European University Institute, RSC Policy Paper 98/5.

Barany, Z. B. (2002). The East European Gypsies: Regime change, marginality and ethnopolitics. Cambridge: Cambridge University Press.

Cashman, L. (2008). 'Implementing national Romani policy at the local level: Experiences of the preparatory class programme in two Czech cities', in M. Flynn, J. Oldfield and R. Kay (eds) Trans-National Issues, Local Concerns: Insights from Russia, Central and Eastern Europe and the UK. Lanham, MD: University Press of America, pp. 159 - 176.

Castle-Kaňerová (2003). 'Round and round the roundabout: Czech Roma and the vicious circle of asylum seeking', Nationalities Papers, 31(1), pp. $13-25$.

Council of Europe (1996). Report of the experts of the Council of Europe on the citizenship laws of the Czech Republic and Slovakia and their implementation and replies of the Governments of the Czech Republic and Slovakia. Strasbourg: Council of Europe/ Directorate Of Legal Affairs COE.M.7/96 RE 1996; DIR/JUR (96) 4. Available at: http://www.coe.int/T/E/Cultural Cooperation/Youth/5. Information services/R esources_by topic/CITIZENSHIP.asp, last accessed 20 October 2005.

Council for Romani Community Affairs (2005a). Usnesení vlády ČR k romským komunitám 1990 - dodnes. Prague: Council of the Government of the Czech Republic for Romani Community Affairs. Available at: http://wtd.vlada.cz/vrk/vrk.htm, last accessed 20 October 2005.

Council for Romani Community Affairs (2005b). The Romani integration policy concept, approved by the Government of the Czech Republic 4 May 2005. Available at: http://wtd.vlada.cz/urad/urad_postaveni.htm, last accessed 19 November 2005.

Council for Romani Community Affairs (2003). Informace o plnění usnesení vlády, týkajících se integrace romských komunit a aktivního postupu státní správy při uskutečnění opatření přijatých těmito usneseními ke dni 31. prosinci 2002. Available at: http://wtd.vlada.cz/urad/urad postaveni.htm, last accessed 7 August 2003.

Czech Statistics Office (CSO) (2001). Obyvatelstvo podle národnosti a krajů k 1.3.2001. Available at:

http://www.czso.cz/csu/2002edicniplan.nsf/publ/180F9F1A8EB21F52C1256D4F 003545E1/\$File/2906.XLS, last accessed 22 June 2007.

Czech Statistics Office (CSO) (2008a). Míra registrované nezaměstnanosti k 31.12.2007 (U060201). Personal communication with Martina Oboraková at the Czech Statistics Office, 18 June 2008.

Czech Statistics Office (CSO) (2008b). Nezaměstnanost podle krajů a okresů k 31.10.2007. Available at: http://www.czso.cz/xc/edicniplan.nsf/t/0F0031D872/\$File/3102q4g3.pdf, last accessed 18 June 2008.

DG Employment and Social Affairs (2004). The situation of Roma in an enlarged European Union. Brussels: European Commission. Available at: http://ec.europa.eu/employment_social/publications/2005/ke6204389_en.pdf, last accessed 17 March 2007.

DG Enlargement Information Unit (2003). European Union support for Roma communities in Central and Eastern Europe. Brussels: Enlargement Information Unit. Available at:

http://ec.europa.eu/comm/enlargement/docs/pdf/brochure roma oct2003 en .pdf, last accessed 11 April 2006.

DG Enlargement (2004). From Pre-Accession to Accession: Review of the European Union Phare assistance to Roma minorities. Interim evaluation of Phare support allocated in 1999-2002 and implemented until November 2003. Report ZZ/MIN/03082. Brussels: European Commission Directorate-General Enlargement, Directorate E - Evaluation Unit. Available at:

http://ec.europa.eu/enlargement/pdf/financial_assistance/Phare/revised_minor ities_thematic_raw_161204_en.pdf, last accessed 15 September 2008.

Directive 2000/43/EC (29 June 2000) implementing the principle of equal treatment between persons irrespective of racial or ethnic origin [2000] O.J. L180/22. Available at: 
http://europa.eu.int/eurlex/pri/en/oj/dat/2000/l 180/l 18020000719en0022002 6.pdf, last accessed 22 October 2006.

Directive 2000/78/EC (27 November 2000) establishing a general framework for equal treatment in employment and occupation [2000] O.J. L303/16. Available at: http://ec.europa.eu/employment social/news/2001/jul/directive78ec en.pdf, last accessed 22 October 2006).

Education Act (2004) Zákon ze dne 24 zárí 2004 o předškolním, základním, středním, vyšším odborném a jiném vzdělávání (školský zákon), Code of Laws No.561/2004 Coll., Part 190, Page 10262. Available at:

http://www.mvcr.cz/sbirka/2004/sb190-04.pdf, last accessed 22 October 2006.

Educational Psychologist (2005). Interview by author, Ostrava, 21 March.

Employment Office Representative 2 (2005). Interview by author. 12 April, Ostrava

Employment Office Representative 2 (2007). Interview by author. 24 October, Ostrava

European Commission (1997). Agenda 2000 - Commission's opinion on the Czech Republic's application for membership of the European Union. Available at: http://europa.eu.int/comm/enlargement/dwn/opinions/czech/cz-op-en.pdf, last accessed 17 October 2005.

European Commission (1998). Regular report from the Commission on the Czech Republic's progress towards Accession. Available at: http://europa.eu.int/comm/enlargement/report 11 98/pdf/en/czech en.pdf, last accessed 17 October 2005.

European Commission (1999). 1999 Regular report from the Commission on the Czech Republic's progress towards accession. Available at: http://europa.eu.int/comm/enlargement/report 10 99/pdf/en/czech en.pdf, last accessed 17 October 2005.

European Commission (2000). 2000 Regular report from the Commission on the Czech Republic's progress towards accession. Available at: http://europa.eu.int/comm/enlargement/report 11 00/pdf/en/czech en.pdf, last accessed 17 October 2005.

European Commission (2001). 2001 Regular report on the Czech Republic's progress towards accession. Available at: http://ec.europa.eu/enlargement/archives/pdf/key documents/2001/cz en.pdf last accessed 21 March 2007.

European Commission (2002). 2002 Regular report on the Czech Republic's progress towards accession. Available at:

http://europa.eu.int/comm/enlargement/report2002/cz en.pdf, last accessed 17 October 2005.

European Commission (2003). 2003 Comprehensive monitoring report on the Czech Republic's preparations for membership. Available at: http://ec.europa.eu/enlargement/archives/pdf/key_documents/2003/cmr_cz_fi nal_en.pdf, last accessed 21 March 2007.

European Roma Rights Centre (ERRC) (2008). Ostrava Case: D.H. and others v. The Czech Republic, Budapest: ERRC. Available at: http://www.errc.org/cikk.php?cikk=2945\&archiv=1, last accessed 14 May 2008.

Fraser, A. (1995). The Gypsies, $2^{\text {nd }}$ edn, Oxford: Blackwell Publishing.

Government of the Czech Republic (1997). Report on the situation of the Romani community in the Czech Republic. Available at: http://www.vlada.cz/1250/eng/vrk/rady/cinnost/romove/cast1.htm, last accessed 27 June 2002.

Government of the Czech Republic (2000). Koncepce politiky vlády vưči přislušníkům romské komunity, napomáhající jejich integraci do společnosti. Available at: http://www.vlada.cz/ASC/vrk/komise/krp/dokumenty/koncepce.pdf, last accessed 15 August 2002.

Government of the Czech Republic (2002). Zpráva o možnostech opatření k odstranění diskriminace. Available at: http://wtd.vlada.cz/files/rvk/rlp/dokumenty/zprava_o_moznostech_opatreni.pd f, last accessed 13 February 2004. 
Government of the Czech Republic (2008). Agentura pro sociální začleňování v romských lokalitách zahajuje činnost $v 12$ obcích a mikroregionech ČR. Available at: http://www.vlada.cz/scripts/detail.php?id=30989, last accessed, 18 June 2008.

Government Resolution (1997a). Usnesení vlády České republiky ze dne 17. zárí 1997 č. 581 o zrízení Meziresortní komise pro záležitosti romské komunity. Available at: http://racek.vlada.cz/usneseni/usneseni webtest.nsf/WebGovRes/6E6DA81118 A87108C12571B6006AE71A?OpenDocument, last accessed 23 October 2006.

Government Resolution (1997b). Usnesení vlády České republiky ze dne 29. řijna 1997 č. $686+P$ ke Zprávě o situaci romské komunity v České republice a $k$ současné situaci $v$ romské komunitě. Available at:

http://racek.vlada.cz/usneseni/usneseni_webtest.nsf/WebGovRes/4AB277D7C7 9B9F38C12571B6006D1F2C?OpenDocument, last accessed 23 october 2006.

Government Resolution (2000). Usnesení vlády České republiky ze dne14. června 2000 č. $599+P$ ke Koncepci politiky vlády vůči přislušníkům romské komunity, napomáhající jejich integraci do společnosti. Available at:

http://racek.vlada.cz/usneseni/usneseni webtest.nsf/WebGovRes/48711C471EF A593BC12571B6006C3E82?OpenDocument, last accessed 23 October 2006.

Government Resolution (2001). Usnesení vlády České republiky ze dne 3. ledna 2001 č. 14 $+P k$ Rozboru poradních a pracovních orgánů vlády a návrhu na jejich systémové řešení. Available at:

http://racek.vlada.cz/usneseni/usneseni webtest.nsf/WebGovRes/6BED6D3928 9B0F96C12571B6006BC2D7?OpenDocument, last accessed 23 October 2006.

Government Resolution (2002). Usnesení vlády České republiky k informaci o plnění usnesení vlády, týkajících se integrace romských komunit a aktivního postupu státní správy při uskutečnění opatření prijiatých těmito usneseními k dni 31. prosinci 2001 $a \quad k$ návrhu Koncepce romské integrace. Available at: http://wtd.vlada.cz/urad/urad postaveni.htm, last accessed 7 August 2003.

Guglielmo, R. (2004). 'Minority rights and EU enlargement: Normative overstretch or effective conditionality?', in G. N. Toggenburg (ed.), Minority protection and the European Union: the way forward, Budapest: OSI/LGI, pp. $59-84$.

Guglielmo, R. and Waters, T.W. (2005). 'Migrating towards minority status: Shifting European policy towards Roma', Journal of Common Market Studies, 43(4), pp. $763-786$.

Guy, W. (1975). 'Ways of Looking at Roms: The Case of Czechoslovakia', in F. Rehfisch, (ed.), Gypsies, Tinkers and other Travellers. London: Academic Press, pp. $201-229$.

Guy, W. (2001). 'The Czech Lands and Slovakia: Another false dawn?', in W. Guy (ed.), Between past and future: The Roma of Central and Eastern Europe. Hatfield: University of Hertfordshire Press, pp.285 - 332.

Guy, W. (2004). 'Asylum in Perspective: Roma migration to the UK', in W. Guy, Z. Uherek and R.Weinerová (eds), Roma migration in Europe: Case Studies. Münster: Lit Verlag, pp. $165-210$.

Hospodářské noviny (2006). Senátoři ODS pozastavili antidiskriminační zákon, 27 January: 3.

Hughes, J. and Sasse, G. (2003). 'Monitoring the monitors: EU enlargement conditionality and minority protection in the CEECs', Journal of Ethnopolitics and Minority Issues in Europe, 1. Available at: http://www.ecmi.de/jemie/download/Focus1-2003 Hughes Sasse.pdf, last accessed 18 June 2008.

iDnes (2008). 'Klaus vetoval antidiskriminační zákon, který žádá EU. Je podle něj zbytečný' 16 May. Available at: http://zpravy.idnes.cz/klaus-vetovalantidiskriminacni-zakon-ktery-zada-eu-je-podle-nej-zbytecny-15s/domaci.asp?c=A080516 112215 domaci jba, last accessed 16 May 2008.

Johns, M. (2003). "'Do as I say, not as I do": The European Union, Eastern Europe and minority rights', East European Politics and Societies, 17(4), pp. $682-699$.

Kelley, J. (2004). 'International actors on the domestic scene: Membership conditionality and socialisation by international actors', International Organisation, 58, pp. 425 $-457$. 
Klímová, I. (2004). 'The current academic debate on the political aspects of Romani migrations and asylum seeking', in W. Guy, Z. Uherek and R. Weinerová (eds) Roma migration in Europe: Case Studies. Münster: Lit Verlag, pp. 11 - 50.

Kostelancik, D. J. (1989). 'The Gypsies of Czechoslovakia: Political and ideological considerations in the development of policy', Studies in Comparative Communism, 22 (4), pp. $307-321$.

Kovats, M. (2001). 'The emergence of European Roma policy', in W. Guy (ed.) Between past and future: The Roma of Central and Eastern Europe. Hatfield: University of Hertfordshire Press, pp. $333-350$.

Kovats, M. (2003). 'The politics of Roma identity: between nationalism and destitution', Open Democracy. Available at: http://www.opendemocracy.net/node/1399/pdf, last accessed 22 April 2007.

Lidové noviny (1999). 'Špidla: Označení "R" není diskriminace', 2 November: 2.

Liégeois, J-P. and Gheorghe, N. (1995). Roma/Gypsies: A European minority. London: Minority Rights Group.

Lipsky, M. (1980). Street-level bureaucracy: dilemmas of the individual in public services. New York: Russell Sage Foundation.

Litomiský, J. (2006). 'Lidská práva? Místo tři ředitelů je jeden', Lidové noviny, 4 October.

Matras, Y. (2000). 'Romani migrations in the Post-Communist Era: The historical and political significance', Cambridge Review of International Affairs, 13(2), pp. 32 - 50.

Ministry of Labour and Social Affairs (MLSA) (2003a). Joint memorandum on social inclusion of the Czech Republic. Brussels: European Commission and MLSA. Available at: http://www.mpsv.cz/files/clanky/5150/memo.pdf, last accessed 9 February 2004.

Ministry of Labour and Social Affairs (MLSA) (2006). Information on unemployment in the Czech Republic - May 2005. Available at: http://www.mpsv.cz/files/clanky/1656/Unemployment_may2005.pdf, last accessed 14 march 2006.

Mirga, A. (2005). Making the EU's anti-discrimination policy instruments work for Romani communities in the enlarged European Union. Princeton: Project on Ethnic Relations. Available at: www.per-usa.org/Reports/Andrzej\%20Mirga\%20_2.PDF, last accessed 17 March 2007.

Mirga, A. and Gheorghe, N. (1997). The Roma in the twenty-first century: A policy paper. Princeton: Project on Ethnic Relations. Available at: http://www.perusa.org/21st c.htm, last accessed 4 October 2003.

Municipal Councillor (2004). Interview by author, 19 November, České Budĕjovice.

Municipal Education Official (2005). Interview by author, 5 April, Ostrava.

Municipal Social Affairs Official (2005). Interview by author, 26 April, Ostrava.

NGO representative 12 (2007). Interview by author, 24 October, Ostrava.

O'Nions, H. (1999). 'Bonafide or Bogus: Roma asylum seekers from the Czech Republic', Web Journal of Current Legal Issues, 3 Available at: http://webjcli.ncl.ac.uk/1999/issue3/onions3.html, last accessed 24 April 2002.

OSCE/CSCE (1993). Roma (Gypsies) in the CSCE Region: Report of the High Commissioner on National Minorities. Prague: OSCE/CSCE Available at:

http://www.osce.org/documents/hcnm/1993/09/3473_en.pdf, last accessed 12 April 2008.

Pravec, J. (2005). 'Lidé snaději vysoudí peníze za diskriminaci', Hospodářské noviny, 8 December.

Pridham, G. (2008). 'Status Quo Bias or Institutionalisation for Reversibility?: The EU's Political Conditionality, Post-Accession Tendencies and Democratic Consolidation in Slovakia', Europe-Asia Studies, 60(3), pp. $423-454$.

Principal 3 (2004). Interview by author, 12 October, České Budějovice.

Principal 7 (2005). Interview by author, 17 March, Ostrava.

Ram, M. (2003). 'Democratization through European integration: The case of minority rights in the Czech Republic and Romania', Studies in Comparative International Development, 38(2), pp. $28-56$. 
Riedel, S. (2001). 'Minderheitenpolitik im Prozess der EU-Erweiterung, Dynamisierung ethnischer Konflikte durch positive Diskriminierung', Osteuropa, 11(12), pp. 1262 $-1285$

Ringold, D., Orenstein, M.A. and Wilkens, E. (2005). Roma in an expanding Europe: Breaking the poverty cycle. Washington D.C.: The World Bank.

Romani Advisor (2007). Interview by author, 7 November, České Budějovice.

Sdružení Dženo (2002). Romové $a$ volby 2002. Available at: http://www.dzeno.cz/volby/otazky_seznam.htm, last accessed 27 June 2002.

South Bohemia Regional Coordinator for Romani Affairs (2004), Interview by author, 6 October, České Budějovice.

South Bohemia Regional Education Official (2004). Interview by author, 11 October, České Budějovice.

Spirova, M. and Budd, D. (2008). 'The EU accession process and the Roma minorities in new and soon-to-be member states', Comparative European Politics, 6, pp. 81 101.

Ulč, O. (1988). 'Gypsies in Czechoslovakia: A case of unfinished integration', Eastern European Politics and Societies, 2(2), pp. $306-332$.

Vermeersch, P. (2004). 'Minority policy in Central Europe: Exploring the impact of the EU's enlargement strategy', The Global Review of Ethnopolitics, 3(2), pp. 3 - 19. 